\title{
Short Communication: Addition of Milk Replacer to Colostrum Whey: Effect on Immunoglobulin G Passive Transfer in Majorera Kids
}

\author{
N. Castro, ${ }^{*}$ J. Capote, $\dagger$ L. Morales, ${ }^{*}$ E. Quesada, ${ }^{*}$ H. Briggs, ${ }^{*}$ and A. Argüello*1 \\ *Department of Animal Science, Las Palmas de Gran Canaria University, Arucas 35416, Spain \\ †Canary Agronomic Science Institute, La Laguna, Tenerife, Spain
}

\begin{abstract}
Forty-two Majorera kids (21 males and 21 females) were assigned to 3 groups, a colostrum group (C), a colostrum whey group $(\mathrm{CW})$, and a colostrum whey plus milk replacer group (CWMR). All kids were fed twice on the first day and received $4 \mathrm{~g}$ of $\mathrm{IgG} / \mathrm{kg}$ of body weight. No differences were found in serum IgG among the different treatments. Kid serum IgG concentrations on $\mathrm{d} 2$ were $14.57,17.25$, and $13.32 \mathrm{mg} / \mathrm{mL}$ in the $\mathrm{C}$, CW, and CWMR group, respectively. Labor time per animal was higher in the $\mathrm{C}$ and $\mathrm{CW}$ treatments than in the CWMR group $(24.2 \pm 2.3,20.9 \pm 3.4$, and $16.1 \pm$ $1.5 \mathrm{~min}$, respectively). This new management system may decrease labor costs during the colostrum feeding period.
\end{abstract}

Key words: goat kid, colostrum whey, immunoglobulin $\mathrm{G}$, milk replacer

To maximize milk returns, natural suckling by kids is not recommended. Thus, to minimize or even annul the mother-kid link, the kids must be removed after parturition and colostrum fed by hand. After the colostrum feeding period, the kids need to learn to suck from silicone teats, which normally takes $2 \mathrm{~d}$. After the colostrum period and learning how to suck, the kids are at least $4 \mathrm{~d}$ old. Commercial goat kid milk replacer formulas are widely used in the dairy goat industry to replace saleable milk in the diet of preweaned kids (Argüello et al., 2004a).

This handling time can be reduced by half if colostrum is mixed with milk replacer at birth, but this mix presents a high density and is very difficult to suck. Therefore, mixing colostrum whey with milk replacer is a suitable solution, because the kids learn in $2 \mathrm{~d}$. Thus, kids learn to suck from silicone teats at the same time that passive Ig transfer may be occurring in the first $2 \mathrm{~d}$ of life.

Received September 25, 2006.

Accepted January 12, 2007.

${ }^{1}$ Corresponding author: aarguello@dpat.ulpgc.es
No literature was found relating to the use of goat colostrum whey as a colostrum replacer for kids, but in calves, Garry et al. (1996) and Mee et al. (1996) did not observe good results using dried whey. The present experiments are the first to approach the use of this product in goat kids, and we try to explain how the source of IgG [goat colostrum (C), goat colostrum whey $(\mathbf{C W})$, or goat colostrum whey plus commercial milk replacer (CWMR)] affects the IgG serum blood concentration in kids. Furthermore, using CWMR from birth may reduce the handling time during the colostrum feeding period.

A colostrum pool was made from fresh goat colostrum (41.23 $\mathrm{mg}$ of IgG/mL of colostrum, $9 \%$ protein, $7 \%$ fat). Half the pool was refrigerated $\left(4^{\circ} \mathrm{C}\right)$ for use as colostrum, and the other half was clotted using commercial cheese rennet (Cuajo Marschall, Rhodia Iberica, Madrid, Spain) containing $50 \%$ chymosin and $50 \%$ bovine pepsin. Colostrum whey was obtained by compressing the curd in the same way as for handmade cheese manufacturing. The IgG of the $\mathrm{CW}$ was evaluated $(52.78 \mathrm{mg}$ of IgG/mL of colostrum, $6 \%$ protein, $1 \%$ fat) and then refrigerated $\left(4^{\circ} \mathrm{C}\right)$ until use.

Forty-two Majorera kids (21 males and 21 females) were randomly assigned to 3 groups. The $\mathrm{C}$ group, the CW group, and the CWMR group were fed their respective form of colostrum by bottle twice on the first day ( 2 and $14 \mathrm{~h}$ postpartum). Each feeding in each group contained 2,000 $\mathrm{mg}$ of IgG/kg of BW in accordance with the management system proposed by Castro et al. (2005). The total IgG received by the 3 groups was 4,000 $\mathrm{mg}$ of IgG/kg of BW. On the first day of life, kids in the $\mathrm{C}$ group received $97 \mathrm{~mL}$ of colostrum $/ \mathrm{kg}$ of $\mathrm{BW}$, kids in the $\mathrm{CW}$ group received $76 \mathrm{~mL}$ of colostrum whey/kg of $\mathrm{BW}$, and kids in the CWMR group received $76 \mathrm{~mL}$ of colostrum whey $+12.1 \mathrm{~g}$ of milk replacer (Bacilactol Cabritos, Biona, Madrid, Spain)/kg of BW (4,000 mg of IgG, $8.8 \%$ protein, $4.66 \%$ fat). From d 2 to 5, the kids were fed by a milk replacer machine (Mini Robot, Divasa Farmavic, Barcelona, Spain) in accordance with Argüello et al. (2004a).

Samples from the jugular vein were taken at birth and every day from birth to $5 \mathrm{~d}$ postpartum to determine 
Table 1. Least squares means of goat kid serum IgG

\begin{tabular}{|c|c|c|c|c|c|c|c|}
\hline \multirow[b]{2}{*}{ IgG source } & \multicolumn{5}{|c|}{ LSM for goat kid serum IgG } & \multirow[b]{2}{*}{ SEM } & \multirow[b]{2}{*}{$\% \mathrm{FPT}$} \\
\hline & Day 1 & Day 2 & Day 3 & Day 4 & Day 5 & & \\
\hline Goat colostrum & 12.03 & 14.57 & 15.08 & 14.42 & 9.89 & 0.85 & 21.43 \\
\hline Goat colostrum whey & $13.89^{\mathrm{ab}}$ & $17.25^{\mathrm{a}}$ & $15.21^{\mathrm{a}}$ & $10.13^{\mathrm{bc}}$ & $8.14^{\mathrm{c}}$ & 0.88 & 0 \\
\hline Goat colostrum whey plus milk replacer & 10.38 & 13.32 & 11.60 & 11.16 & 9.32 & 0.52 & 7.14 \\
\hline
\end{tabular}

the IgG concentration in the kids' blood, using the method of Mancini et al. (1965). The standard curve was prepared in accordance with Catty and Raykundalia (1988) using a goat IgG solution $(50 \mathrm{mg} / \mathrm{mL})$. Labor time per animal was recorded with a stopwatch during the first $5 \mathrm{~d}$ of life.

All variables were distributed normally. The statistical analysis used to evaluate the effects of IgG source and birth weight on the IgG blood serum of kids was a GLM procedure with repeated measures between the 3 groups. An ANOVA was performed to evaluate the effect of IgG source on labor time (SPSS Inc., 1988).

No statistically significant differences were observed in birth weights among the 3 groups $(3,542,3,381$, and 3,313 $\mathrm{g}$ for C, CW, and CWMR, respectively). Source of IgG was not significantly associated with serum IgG concentrations at $1,2,3,4$, and $5 \mathrm{~d}$ of age (Table 1 ). Blood concentrations of IgG ranged from 17.25 to 8.14 $\mathrm{mg} / \mathrm{mL}$, similar to those reported by Castro et al. (2005) in the same breed. O'Brien and Sherman (1993) have defined failure of passive transfer (FPT) in the kid as a serum IgG concentration of less than $12 \mathrm{mg} / \mathrm{mL}$, using a spectrophotometric zinc sulfate turbidity assay. In addition, Argüello et al. (2004b) found an IgG blood concentration of $4.85 \mathrm{mg} / \mathrm{mL}$ in dead kids at $48 \mathrm{~h}$ postpartum. Not one of the kids in the present experiment showed an IgG blood concentration of less than 4.85 $\mathrm{mg} / \mathrm{mL}$. According to O'Brien and Sherman's (1993) definition of FPT, $21.43 \%$ of the C kids presented FPT, whereas just 7.14 and $0 \%$ of the CW or CWMR kids, respectively, presented FPT. Peak serum IgG concentrations were observed on $\mathrm{d} 3$ for the $\mathrm{C}$ group and on d 2 for the CW and CWMR groups (Table 1).

In all 3 groups, the kids' IgG serum concentrations were slightly higher than those reported by Castro et al. (2005) in the same breed using frozen and lyophilized colostrum because of differences in IgG in the formula per kilogram of BW (3,368 vs. 4,000 mg of IgG/kg of BW; Castro et al., 2005, and the present study, respectively). Constant et al. (1994) tried a colostrum replacer based on goat serum blood, which had a low passive transfer of IgG. However, no references regarding the use of CW in goats have been found, although some experiments have been performed in calves. Garry et al. (1996) and Mee et al. (1996) did not observe good results when using dried whey. Thus, the results in the present study showed good performance for animals using CW, opposite the results shown in calves. The reason for these differences might arise from the different origins of whey; the calf experiment used whey derived from milk manufacture, whereas in the present study, the whey was derived from colostrum.

Milk replacer with added bovine or porcine plasma protein was tested by Quigley and Wolfe (2003), and no differences were found in plasma IgG concentrations. Jones et al. (2004), using a commercial colostrum replacer based on cow serum (Acquire, APC, Inc., Ankeny, IA), reported similar plasma IgG values for calves fed colostrum and a colostrum replacer. The $\mathrm{CW}$ used in the present study showed a higher IgG concentration than the $\mathrm{C}$ because large amounts of fat and $\mathrm{CN}$ were removed. This reduced $\mathrm{CN}$ content may have improved the transfer of IgG to the blood, in accordance with the report by Davenport et al. (2000) that an excess of CN in colostrum supplements may decrease IgG absorption. Besser and Osbourn (1993) hypothesized that an increase in protein colostrum intake depressed the serum IgG concentration. The CWMR presented a higher protein content than the $\mathrm{C}$ and $\mathrm{CW}$, but not enough to reduce the kid serum IgG concentration.

Labor times per animal during the first $5 \mathrm{~d}$ of life were $24.2 \pm 2.3,20.9 \pm 3.4$, and $16.1 \pm 1.5 \mathrm{~min}$ for the $\mathrm{C}, \mathrm{CW}$, and CWMR group, respectively. Labor time for the CWMR group was statistically less than those for the $\mathrm{C}$ and $\mathrm{CW}$ groups. Goat kids required less labor time on the first day because the mix between colostrum whey and milk replacer was less dense, and the labor time on the second day was also less because the taste did not change much.

In this study, no significant effects of birth weight on blood serum IgG were observed (Figure 1). Bekele et al. (1992), who reported similar results for lambs, also failed to find differences in Ig blood concentrations between lambs born weighing 1 to $1.5 \mathrm{~kg}$ and those with birth weights of more than $3 \mathrm{~kg}$. Although no differences were found, there was a tendency for IgG concentra- 


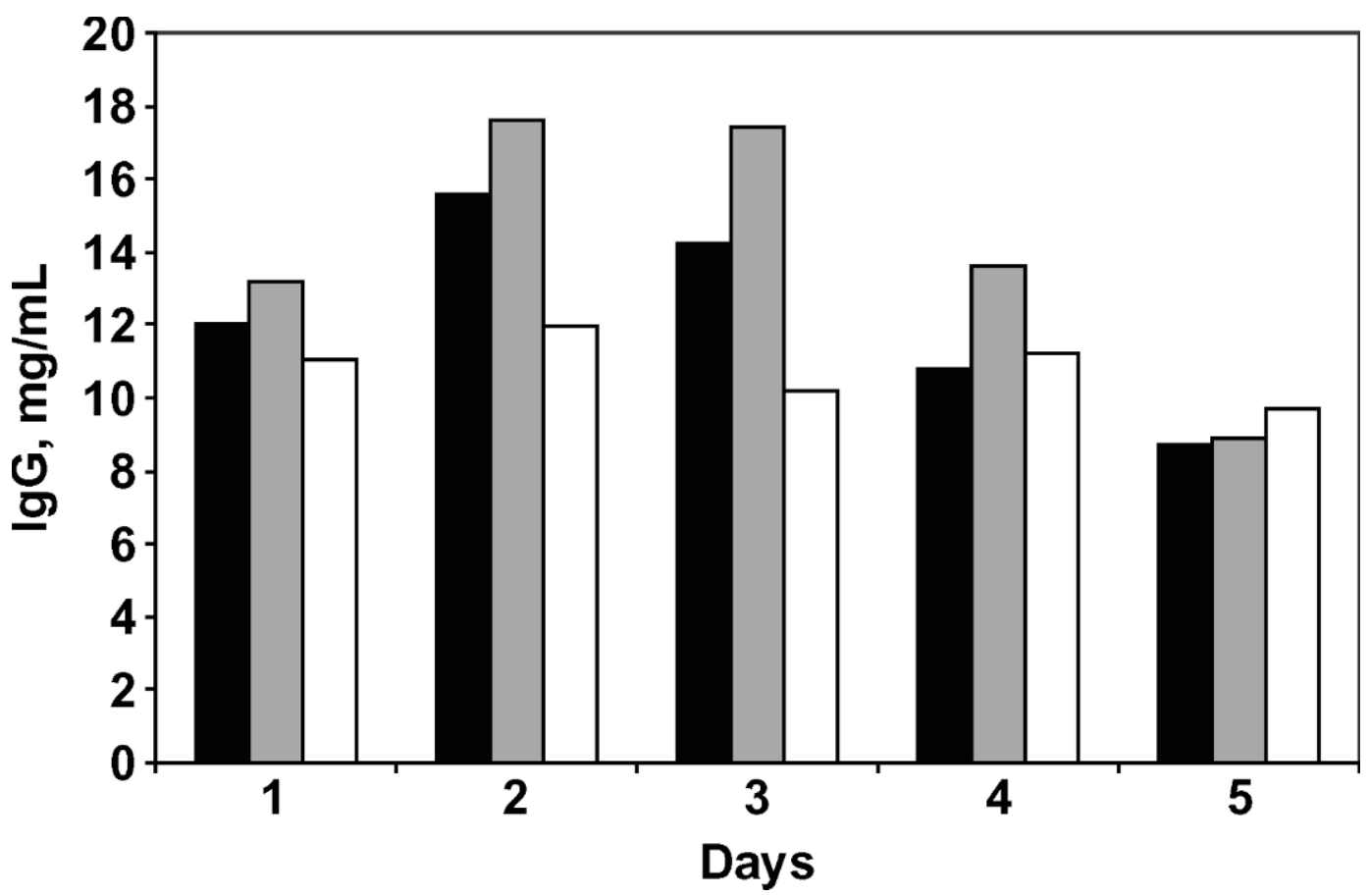

Figure 1. Kids' serum IgG $(\mathrm{mg} / \mathrm{mL})$ concentration by birth weight. Solid bars = birth weights below $2.5 \mathrm{~kg}$; gray bars = birth weights between 2.5 and $3.2 \mathrm{~kg}$; open bars = birth weights over $3.2 \mathrm{~kg}$.

tions to increase when birth weights were between 2.5 and $3.2 \mathrm{~kg}$.

Management of the CWMR may reduce labor costs for the goat keeper as the kids start to receive milk replacer at birth. The colostrum feeding period is an expensive time in terms of labor costs because of the importance of good passive IgG transfer from the colostrum to the kid's blood serum. However, this new management technique allowed the colostrum feeding period to be avoided, replacing it with a CWMR period and maintaining the same kid IgG blood serum levels.

\section{REFERENCES}

Argüello, A., N. Castro, and J. Capote. 2004a. Growth of milk replacer kids fed under three different managements. J. Appl. Anim. Res. 25:37-40.

Argüello, A., N. Castro, J. Capote, J. W. Tyler, and N. M. Holloway. 2004b. Effect of colostrum administration practices on serum IgG in goat kids. Livest. Prod. Sci. 90:235-239.

Bekele, T., E. B. Otesile, and O. B. Kasali. 1992. Influence of passively acquired colostral immunity on neonatal lamb mortality in Ethiopian highland sheep. Small Rumin. Res. 9:209-215.

Besser, T. E., and D. Osbourn. 1993. Effects of bovine serum albumin on passive transfer of immunoglobulin G1 to newborn calves. Vet. Immunol. Immunopathol. 37:321-327.

Castro, N., J. Capote, S. Alvarez, and A. Argüello. 2005. Effects of lyophilized colostrum and different colostrum feeding regimens on passive transfer of immunoglobulin $\mathrm{G}$ in Majorera goat kids. J. Dairy Sci. 88:3650-3654.
Catty, D., and C. Raykundalia. 1988. Gel immunodiffusion, immunoelectrophoresis and immunostaining methods. Pages 137-167 in Antibodies. D. Catty, ed. IRL Press, Oxford, UK.

Constant, S. B., M. M. Leblanc, E. F. Klapstein, D. E. Beebe, H. M. Leneau, and C. J. Nunier. 1994. Serum immunoglobulin G concentration in goats kids fed colostrum or a colostrum substitute. J. Am. Vet. Med. Assoc. 205:1759-1762.

Davenport, D. F., J. D. Quigley, III, J. E. Martin, J. A. Holt, and J. D. Arthington. 2000. Addition of casein or whey protein to colostrum or a colostrum supplement product on absorption of IgG in neonatal calves. J. Dairy Sci. 83:2813-2819.

Garry, F. B., R. Adams, M. B. Cattell, and R. P. Dinsmore. 1996. Comparison of passive immunoglobulin transfer to dairy calves fed colostrum or commercially available colostral-supplement products. J. Am. Vet. Med. Assoc. 208:107-110.

Jones, C. M., R. E. James, J. D. Quigley, III, and M. L. McGilliard. 2004. Influence of pooled colostrum or colostrum replacement on IgG and evaluation of animal plasma in milk replacer. J. Dairy Sci. 87:1806-1814.

Mancini, G., A. O. Carbonara, and J. F. Heremans. 1965. Immunochemical quantitation of antigens by single radial immunodiffusion. Immunochemistry 2:235-254.

Mee, J. F., K. J. O'Farrel, P. Reitsma, and R. Mehra. 1996. Effects of a whey protein concentrate used as a colostrum substitute or supplement on calf immunity, weight gain, and health. J. Dairy Sci. 79:886-894.

O'Brien, J. P., and D. M. Sherman. 1993. Serum immunoglobulin concentrations of newborn goat kids and subsequent kid survival through weaning. Small Rumin. Res. 11:71-77.

Quigley, J. D., III, and T. M. Wolfe. 2003. Effects of spray-dried animal plasma in calf milk replacer on health and growth of dairy calves. J. Dairy Sci. 86:586-592.

SPSS Inc. 1988. User's Guide, SPSS. 3rd ed. SPSS Inc., Chicago IL. 